\title{
MANAJEMEN PENDIDIK DAN TENAGA KEPENDIDIKAN DALAM MENINGKATKAN MUTU PENDIDIKAN
}

\author{
NURLINDAH, MUH. KHALIFAH MUSTAMI, MUSDALIFAH \\ Pascasarjana Universitas Islam Negeri Alauddin Makassar \\ Email: nurlindah947@gmail.com, muhkhalifahmustami@uin-alauddin.ac.id, \\ gaffarmusdalifah@gmail.com
}

\begin{abstract}
:
The purpose of this research is to reveal the activity of management realization and personel education and find an effort done to increase the quality education by education management and personel education. The kind of this research is descriptive qualitative research in Al-Mansur Biangloe boarding school Bantaeng regency. Data collection methods by interview, observation and documentation. The result of research show that the implementation educator management and personel education at palnning step, selection, orientation, appointment and placement, observation and assessment, giving compensation and discharge have been done but it is not still maximal, there are still educator and staf education not based on their expert, compensation given is not able to make prosperous for them. The things to do to increase the quality by good planning, and selecting of what the school need, developing by training, sertified, observation and compensation as a fair to defend educator.
\end{abstract}

Keywords: Management, educator and education personnel, quality of education

\section{PENDAHULUAN}

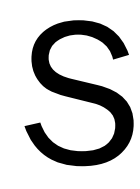

Sumber daya manusia (SDM) pendidikan merupakan seluruh manusia yang terlibat dalam aktivitas pendidikan yang mempengaruhi kegiatan manajemen dalam organisasi. SDM pendidikan tersebut terdiri dari pimpinan, kepala sekolah/madrasah, guru/pendidik, peserta didik, tenaga administrasi dan lain sebagainya.

SDM pendidikan menjadi faktor penting dalam menjalankan manajemen pendidikan, dengan kontribusinya dalam penyelenggaraan pendidikan dapat menciptakan manusia yang bermutu. Pendidik dan tenaga kependidikan sebagai salah satu sumber daya manusia merupakan tenaga yang memegang peran penting dan strategis terutama dalam upaya meningkatkan mutu pendidikan, karena pendidik dan tenaga kependidikan kesehariannya secara langsung berinteraksi dengan peserta didik.

Manajemen pendidik dan tenaga kependidikan dalam penelitian ini merupakan rangkaian aktivitas yang dilaksanakan dimulai dari perencanaan pengadaan pendidik dan tenaga kependidikan, rekrutmen dan seleksi, pengangkatan dan penempatan, orientasi, kompensasi, pengawasan dan penilaian serta pengembangan sampai pada pemberhentian.

Mutu selain menjadi kebutuhan yang mendesak, terdapat realitas di lapangan bahwa faktor yang sering disorot dan diperhatikan oleh pemerintah atau pemangku kebijakan adalah melakukan perubahan dari segi programnya tanpa dibarengi dengan upaya yang selaras dan seimbang dengan upaya membenahi orangnya yaitu tenaga kependidikan, demikian juga halnya dengan manajemen dan pengelolaan pendidikan oleh pimpinan terhadap institusinya (Novia dan Wildansyah, 
2017). Masalah tersebut jelas sangat mempengaruhi mutu pendidikan, hal ini menjadi tugas berat dan tanggung jawab bagi pemangku kebijakan dan kepala satuan pendidikan untuk mampu menata dan mengelola manajemen pendidik dan tenaga kependidikan dalam menjalankan tugas dan tanggung jawabnya.

Beberapa asumsi dasar yang melatar belakangi pendidik dan tenaga kependidikan sebagai sumber daya manusia menjadi faktor strategis dan rasional yang menentukan tingkat keberhasilan dalam sistem pendidikan yakni: 1) manusia merupakan aset terpenting dalam organisasi pendidikan, 2) personil menentukan keberhasilan tujuan pendidikan, 3) unsur manusia merupakan variabel terkontrol paling besar dalam organisasi, 4) sebagian besar persoalan organisasi berkaitan dengan penampilan manusia, 5) perhatian utama dari sistem sekolah adalah mengidentifikasi dan memenej perilaku proses agar mencapai tujuan yang ditetapkan (Mudassir, 2016).

Berdasarkan asumsi tersebut maka keberadaan pendidik dan tenaga kependidikan sangat penting sehingga pengelolaan dan pengembangan sumber daya manusia harus dilakukan secara tepat. Pengelolaannya bukan hanya sekedar pengadaan sumber daya manusia, melainkan harus dengan menggunakan fungsifungsi manajemen, mulai dari perencanaan yang matang, melakukan rekrutmen dan seleksi, pengangkatan dan penempatan sesuai dengan latar belakang pendidikannya, pemberian kompensasi secara adil, serta melakukan pengawasan dan penilaian agar tugas dan tanggung jawab pendidik dan tenaga kependidikan searah dengan tujuan pendidikan yang telah ditetapkan. Namun, di MTs Al-Mansur Biangloe Kabupaten Bantaeng berdasarkan observasi terdahulu bahwa di MTs AlMansur Biangloe Kabupaten Bantaeng telah menggunakan fungsi-fungsi manajemen tetapi belum maksimal khususnya dalam proses pengadaan pendidik dan tenaga kependidikan, seperti rekrutmen yang dapat dilakukan secara tiba-tiba tanpa perencanaan yang matang atau merekrut tidak sesuai dengan kompetensi serta mengangkat pendidik pada bidang yang tidak sesuai dengan latar belakang pendidikannya. Oleh sebab itu, penelitian ini dilakukan dengan tujuan untuk mengungkapkan aktivitas pelaksanaan manajemen pendidik dan tenaga kependidikan dan menemukan upaya yang dilakukan dalam meningkatkan mutu pendidikan melalui manajemen pendidik dan tenaga kependidikan.

\section{METODE PENELITIAN}

Jenis penelitian yang digunakan adalah penelitian kualitatif deskriptif yang dilakukan di MTs Al-Mansur Biangloe Kabupaten Bantaeng dengan menggunakan pendekatan metodologi yaitu melalui pendekatan fenomonologi, pendekatan yuridis, pendekatan sosiologis dan pendekatan pedagogis. Sumber data dalam penelitian ini adalah kepala madrsah, wakil kepala madrasah, guru, tenaga administrasi madrasah, tenaga perpustakaan, dan tenaga laboratorium dengan jumlah sampel informan yang di ambil adalah sebelas orang. Teknik pengumpulan data yang digunakan adalah observasi, wawancara dan dokumentasi dengan menggunakan instrumen penelitain kualitatif yaitu peneliti sendiri kemudian dikembangkan dengan instrumen lain seperti instrumen pedoman wawancara, pedoman observasi dan pedoman dokumentasi. Pengolahan data dan analisis data dalam penelitian ini menggunakan deskriptif kualitatif, proses pengolahan datanya dilakukan bersamaan dengan proses berlangsungnya pengumpulan data, seperti saat melakukan 
wawancara peneliti telah melakukan analisis data dari informasi atau jawaban yang didapatkan dari informan. Analis datanya dilakukan sejak sebelum memasuki lapangan, selama di lapangan, dan setelah selesai di lapangan dengan mengikuti teori Miles dan Huberman (1984) yang dilakukan secara interaktif dan terus menerus sampai tuntas, dalam aktivitasnya melalui tiga tahap yaitu reduksi data, display data dan kesimpulan/verifikasi data. Adapun pengujian keabsahan data dalam penelitian ini dilakukan melalui uji kredibilitas data (credibilty), yaitu dengan teknik triangulasi dan member check.

\section{HASIL PENELITIAN DAN PEMBAHASAN}

\section{Pelaksanaan Manajemen Pendidik dan Tenaga Kependidikan di MTs AI-Mansur Biangloe Kabupaten Bantaeng}

\section{Perencanaan Pengadaan Pendidik dan Tenaga Kependidikan}

Hasil penelitian menunjukkan bahwa perencanaan pengadaan pendidik dan tenaga kependidikan di MTs Al-Mansur Biangloe Kabupaten Bantaeng merupakan kegiatan yang dilakukan oleh kepala madrasah sebelum merekrut pendidik dan tenaga kependidikan yaitu dengan melihat latar belakang pendidikan pelamar dan kebutuhan madrasah.

Perencanaan pendidik dan tenaga kependidikan merupakan kegiatan untuk menentukan kebutuhan tenaga kependidikan, baik secara kuantitatif maupun kualitatif untuk sekarang dan masa depan. Penyusunan rencana tenaga kependidikan yang baik memerlukan informasi yang lengkap dan jelas tentang pekerjaan atau tugas yang harus dilakukan dalam organisasi. Karena itu, sebelum menyusun rencana, perlu dilakukan analisis pekerjaan (job analysis) dan analisis jabatan untuk memperoleh deskripsi pekerjaan (E. Mulyasa, 2009: 43). Kepada kepala madrasah sebagai tenaga kependidikan yang mengelola dan memegang tugas utama dalam melakukan perencanaan diharapkan dapat melakukan analisis pekerjaan dan analisis jabatan sebelum menentukan perencanaan pengadaan pendidik dan tenaga kependidikan guna untuk memenuhi kebutuhan madrasah.

Perencanaan dikenal dua metode, yaitu metode perencanaan tradisional dan metode perencanaan terintegrasi. Metode perencanaan tradisional disebut sebagai perencanaan tenaga kerja semata-mata memperhatikan masalah jumlah tenaga kerja serta jenis dan tingkat keterampilan dalam organisasi dan metode perencanaan terintegrasi tidak lagi berpusat pada masalah pasokan dan permintaan tenaga kerja. Dalam perencanaan terintegrasi segala perencanaan berpusat pada visi strategik, yang kemudian visi tersebut dijadikan standar pencapaian (Idris, 2014: 63). Hasil penelitian menunjukkan bahwa metode perencanaan yang digunakan oleh kepala MTs Al-Mansur Biangloe Kabupaten Bantaeng yaitu metode perencanaan tradisional karena hanya memerhatikan masalah kekosongan jabatan tanpa memusatkan perhatian pada visi sebagai standar pencapaian, sehingga hal ini dapat mengakibatkan perencanaan pengadaan pendidik dan tenaga kependidikan yang direkrut nantinya kurang tepat. 


\section{Rekrutmen dan Seleksi}

Hasil penelitian menunjukkan bahwa kepala MTs Al-Mansur Biangloe Kabupaten Bantaeng telah melakukan rekrutmen dan seleksi untuk mengisi kekosongan jabatan dalam organisasi. Kepala MTs Al-Mansur Biangloe Kabupaten Bantaeng dalam merekrut pendidik dan tenaga kependidikan sekalipun telah memerhatikan kualifikasi pelamar, namun masih tetap menerima tenaga yang tidak sesuai dengan kualifikasi yang dibutuhkan. Hal ini tentunya dapat memberikan dampak yang kurang baik terhadap pencapaian mutu pendidikan terlebih lagi terdapat tujuan yang harus dicapai dalam proses rekrutmen dan seleksi.

Rekrutmen merupakan proses mencari, mengadakan, menemukan, dan menarik para pelamar untuk dipekerjakan dalam organisasi (Sutrisno, 2014: 46). Rekrutmen dimulai dari pengumuman penerimaan pegawai, pendaftaran, pengetesan, pengumuman diterimanya pegawai sampai dengan daftar ulang (Mustari, 2015: 214). Demikian maka rekrutmen merupakan proses yang dimulai dengan pencarian dan berakhir sampai lamaran calon pegawai diterima. Tujuannya yaitu untuk mengisi kekosongan jabatan dengan personil yang memenuhi persyaratan yang telah ditentukan dan dinilai mampu menjalankan tugas dalam jabatannya, mendapatkan kepuasan sehingga dapat bertahan dalam sistem, menjadi kontributor efektif bagi pencapaian tujuan dan memiliki motivasi untuk mengembangkan diri (Tim Dosen Administrasi Pendidikan UPI, 2011: 237).

Seleksi didefenisikan sebagai suatu proses pengambilan keputusan individu dipilih untuk mengisi suatu jabatan yang didasarkan pada penilaian terhadap seberapa besar karakteristik individu yang bersangkutan, sesuai dengan yang dipersyaratkan oleh jabatan (Tim Dosen Administrasi Pendidikan UPI, 2011: 237). Tujuan tahap ini dilakukan untuk memilih dari beberapa calon pelamar yang paling tepat untuk mengisi lowongan atau jabatan yang harus diisi.

Hasil penelitian menunjukkan bahwa proses rekrutmen pendidik dan tenaga kependidikan yang dilakukan kepala MTs AI-Mansur Biangloe Kabupaten Bantaeng melalui dua jalur yaitu melalui proses seleksi dan tanpa seleksi atau dilakukan dengan dua cara yaitu memanggil dan menerima. Memanggil maksudnya adalah kepala madrasah secara pribadi menghubungi seseorang yang dianggap kompeten untuk memegang tugas sebagai pendidik ataupun sebagai tenaga kependidikan lainnya untuk mengisi kekosongan jabatan dalam madrasah tanpa dilakukan seleksi. Menerima merupakan cara perekrutan yang dilakukan melalui proses seleksi.

Untuk mendapatkan tenaga yang berkualitas dan dengan jumlah yang memadai maka dibutuhkan metode rekrutmen dan seleksi yang tepat dilandasi dengan perencanaan yang matang. Dalam melakukan perekrutan pihak madrasah menentukan kualifikasi yang dijadikan acuan pendidik dan tenaga kependidikan agar dapat menemukan seseorang yang sesuai dengan jabatan yang diharapkan dan mempunyai kinerja yang bagus dalam menyelesaikan tugas (Mukhlisoh, 2018: 242). 
Tenaga yang diterima tidak sesuai dengan kualifikasi yang dibutuhkan tentu tidak dapat mewujudkan tujuan dari proses rekrutmen dan seleksi tersebut, kecuali jika dilakukan berbagai upaya pelatihan dan pengembangan kompetensi yang berkelanjutan bagi mereka yang sudah terlanjur direkrut, karena pelatihan dan pengembangan adalah suatu usaha untuk meningkatkan pengetahuan dan kemampuan tenaga kependidikan dalam melaksanakan pekerjaanya agar lebih efektif dan efisien (Syukur, 2015: 85).

\section{Pengangkatan dan Penempatan}

Hasil penelitian di MTs Al-Mansur Biangloe Kabupaten Bantaeng menunjukan bahwa masih terdapat pendidik dan tenaga kependidikan yang menjabat tidak sesuai dengan kualifikasi pendidikannya. Hal ini menunjukan bahwa proses pengangkatan dan penempatan yang dilakukan belum maksimal. Sementara pengangkatan dan penempatan merupakan pembagian tugas para personil sekolah baik tenaga pendidik yang lama maupun tenaga pendidik yang baru dengan mempertimbangkan kesesuaian latar belakang pendidikan dengan penempatan ini akan meminimalis kesenjangan dalam penguasaan materi yang akan disampaikan kepada peserta didik (Mukhlisoh, 2018: 244). Sebagaimana diketahui bahwa pengangkatan dan penempatan merupakan proses penanganan pegawai baru yang telah melaksanakan pendaftaran ulang untuk diberitahu pada bidang mana mereka ditempatkan (Mustari, 2015: 214).

Pengangkatan dan penempatan merupakan pembagian tugas para personil sekolah baik tenaga pendidik yang lama maupun tenaga pendidik yang baru dengan mempertimbangkan kesesuaian latar belakang pendidikan dengan penempatan ini akan meminimalis kesenjangan dalam penguasaan materi yang akan disampaikan kepada peserta didik (Mukhlisoh, 2018: 244). Demikian, maka pengangkatan dan penempatan tidak serta-merta dilakukan tanpa melalui pertimbangan atas kemampuan dan kesiapan pendidik dan tenaga kependidikan dalam melaksanakan tugas dan tanggung jawabnya. Agar para personel dapat melaksanakan tugasnya secara tepat guna, berdaya guna dan berhasil guna, mereka perlu ditata berdasarkan prinsip "The right man on the right place and the right men in the right job” (Hasibuan, 2008: 173). Prinsip ini perlu diterapkan untuk menghindari terjadinya mismanagement dalam kepegawaian.

\section{Orientasi}

Setiap penerimaan tenaga baru sebaiknya dilakukan orientasi untuk memudahkan tenaga baru dalam proses adaptasi dengan lingkungan kerja. Adapun hasil penelitian bahwa proses orientasi di MTs Al-Mansur Biangloe Kabupaten Bantaeng belum pernah dilakukan secara resmi melainkan hanya dilakukan induksi yaitu pengenalan singkat antara tenaga yang baru diterima dengan tenaga yang sudah lama bekerja dilakukan pada saat rapat pembagian tugas serta pengenalan 
dasar tentang lingkungan madrasah seperti keadaan madrasah, lingkungan madrasah, keadaan para guru dan keadaan siswa-siswanya yang dilakukan kepala MTs Al-Mansur Biangloe Kabupaten Bantaeng bersamaan ketika dilakukan wawancara penerimaan tenaga baru.

Kegiatan orientasi bermaksud memberikan kesiapan sikap mental dan sosial, kepada pegawai baru supaya dapat mengefektifkan segala potensi yang dimilikinya secara maksimal dalam lingkungan kerja yang baru (Asmara, 2015: 166). Proses orientasi ini dilakukan setelah para pelamar diterima melalui seleksi. Orientasi yang berarti penyediaan informasi dasar berkenaan dengan organisasi yaitu informasi yang diperlukan dan dibutuhkan untuk melaksanakan pekerjaan dengan memuaskan (Syukur, 2015: 82). Demikian pentingnya proses orientasi dilakukan.

\section{Kompensasi}

Hasil penelitian di MTs Al-Mansur Biangloe Kabupaten Bantaeng menunjukkan bahwa kompensasi yang diberikan belum mampu mensejahterahkan kehidupan pendidik dan tenaga kependidikan. Sekalipun ada tenaga yang merasa sudah cukup tetapi tidak sedikit yang masih merasa kekurangan. Dilihat dari jumlah pendidik dan tenaga kependidikannya yang masih lebih banyak berstatus pegawai non-PNS. Sekalipun demikian, karena doktrin kerelaan yang ditanamkan dalam diri pendidik maupun tenaga kependidikan mereka mampu bertahan dan tetap menjalankan tugas dan tanggung jawabnya semaksimal mungkin. Di MTs Al-Mansur Biangloe Kabupaten Bantaeng dari keseluruhan pendidik dan tenaga kependidikannya berjumlah 23 orang dan yang berstatus PNS hanya 3 orang, sehingga selebihnya membutuhkan sistem pemberian kompensasi berdasarkan kebijakan dari madrasah.

Kompensasi sebagai salah satu fungsi yang penting dalam menajemen sumber daya manusia. Karena kompensasi merupakan salah satu aspek yang paling sensitif di dalam hubungan kerja (Sutrisno, 2014: 180). Kompensasi biasa juga disebut dengan gaji, balas jasa dan pemberian upah. Kompensasi dapat dapat diberikan dalam berbagai macam bentuk seperti pemberian uang, materi dan fasilitas serta dalam bentuk pemberian kesempatan mengembangkan karir. Pemberian uang secara langsung seperti gaji, tunjangan dan insentif. pemberian kompensasi telah di atur oleh pemerintah yaitu bagi tenaga pendidik dan kependidikan yang berstatus sebagai pegawai negeri sipil (PNS) pemerintah telah mengatur pemberian kompensasi ini dengan dikeluarkannya Undang-Undang Nomor 43 Tahun 1999 tentang penyesuaian gaji pokok PNS, PP Nomor 3 Tahun 2006 tentang Tunjangan Jabatan Struktural, PP Nomor 12 Tahun 2006 tentang Tunjangan Umum bagi pegawai negeri sipil (PNS). Bagi pendidik dan tenaga kependidikan yang berstatus sebagai non-PNS kebijakan pemberian kompensasi ini didasarkan pada kebijakan lembaga atau yayasan (Tim Dosen Administrasi Pendidikan UPI, 2011: 246). 
Pemberian kompensasi merupakan upaya untuk mempertahankan dan memelihara semangat kerja bagi pendidik dan tenaga kependidikan, hal ini harus dilakukan untuk tetap menjaga eksistensi lembaga pendidikan. Berdasarkan hasil penelitian di lapangan bahwa system pemberian kompensasi kepada pendidik yang statusnya non-PNS diberikan sesuai kebijakan yang ditetapkan oleh madrasah yaitu diberikan dengan menyesuaikan jumlah jam mengajar bagi pendidik yaitu Rp 6.000/jam yang diberikan sekali dalam 2 bulan atau tiga bulan, adapun kompensasi bagi tenaga kependidikan lainnya atau tenaga struktural yaitu guru-guru yang ditugaskan diluar tanggung jawab mengajar diberikan kompensasi berupa insentif yang besarannya juga ditetapkan oleh madrasah. Hal ini dapat menjadi motivasi bagi pendidik untuk dapat meningkatkan kinerjanya sehingga mampu diberikan tanggungjawab di luar jam mengajar sebagai tambahan tugas untuk memperoleh kompensasi yang lebih tinggi. Ketetapan tersebut menjadi struktur yang jelas bagi pendidik dan tenaga kependidikan pada penerimaan kompensasi. Kompensasi yang diberikan sesuai dengan hirarki tugas dan tanggungjawab yang diemban, dengan demikian keadilan dalam cara pemberian kompensasi dapat dirasakan oleh seluruh pendidik dan tenaga kependidikan.

\section{Pengawasan dan Penilaian}

Hasil penelitian di MTs Al-Mansur Biangloe Kabupaten Bantaeng menunjukan bahwa pengawasan dan penilaian oleh kepala madrasah sebagai supervisor internal itu dilakukan setiap ada kesempatan tidak terstruktur atau tidak terjadwal, berbeda dengan pengawasan yang dilakukan oleh supervisor eksternal dari kemenag dilakukan satu kali setiap semester. Keberhasilan proses pengawasan ditentukan oleh penilaian secara rinci yang dapat memberikan umpan balik berupa gambaran yang jelas tentang tingkat keberhasilan dalam mencapai tujuan dan sasaran yang telah ditetapkan. Penilaian kinerja adalah suatu metode formal untuk mengukur seberapa baik pekerja individual melakukan pekerjaan dalam hubungan dengan tujuan yang diberikan (Wibowo, 2017: 188). Dikatakan juga bahwa penilaian prestasi atau evaluasi kinerja merupakan penilaian yang dilakukan secara sistematis untuk mengetahui hasil pekerjaan pegawai dan kinerja organisasi. Disamping itu, juga untuk menentukan kebutuhan pelatihan kerja secara tepat, memberikan tanggung jawab yang sesuai kepada pegawai sehingga dapat melaksanakan pekerjaan yang lebih baik di masa mendatang dan sebagai dasar untuk menentukan kebijakan dalam hal promosi jabatan atau penentuan imbalan (Kasmawati, 2012: 55).

Untuk dapat menjadi pendidik dan tenaga kependidikan yang profesional maka tidak lepas dari upaya madrasah untuk memberikan dukungan secara terus menerus dengan selalu memerhatikan kinerja tenaganya. Hal ini membutuhkan pengawasan dan penilaian terhadap kinerja agar tetap bekerja sesuai dengan yang diharapkan. Salah satu bentuk pengawasan yang dilaksanakan pada unit kerja yang berbentuk Unit Pelaksana Teknis (UPT) sekolah adalah supervisi yang lebih dikenal dengan 
supervisi pendidikan atau supervisi pembelajaran. Supervisi pendidikan adalah pelayanan (service) untuk membantu, mendorong, membimbing serta membina guru-guru agar mampu meningkatkan kemampuan dan keterampilan dalam menjalankan tugas pembelajaran (Supardi, 2016: 76). Kepala sekolah sebagai pemimpin menjadi titik berat dari pelaksanaan supervisi pendidikan yang disebut sebagai supervisor terhadap guru dan tenaga kependidikan di sekolah.

\section{Pemberhentian}

Berdasarkan hasil penelitian di MTs Al-Mansur Biangloe Kabupaten Bantaeng bahwa selama ini belum pernah terjadi pemberhentian secara tidak hormat bagi pendidik dan tenaga kependidikan. Hal ini mencerminkan suasana kerja yang tenang.

Pemberhentian pendidik dan tenaga kependidikan di madrasah merupakan pemutusan hubungan kerja pada suatu madrasah terhadap pendidik dan tenaga kependidikan sehingga pemberhetian ini merupakan fungsi operatif terakhir manajemen sumber daya manusia (Tim Dosen Administrasi Pendidikan UPI, 2011: 250). Di MTs Al-Mansur Biangloe Kabupaten Bantaeng terdapat dua jenis status kepegawaian, yaitu ada yang berstatus PNS (Pegawai Negeri Sipil) dan non-PNS atau honorer. Pemberhentian pendidik dan tenaga kependidikan hanya dapat dilakukan dengan alasan yang jelas dan tepat. Adapun batas usia pensiun untuk guru PNS adalah 65 tahun sedangkan untuk tenaga kependidikan PNS adalah 58 tahun (Karnati, 2016: 189).

\section{Mutu Pendidikan}

Berdasarkan hasil penelitian di lapangan bahwa MTs Al-Mansur Biangloe Kabupaten Bantaeng telah menyelenggarakan pendidikan semaksimal mungkin sehingga mampu memberi kepuasan kepada peserta didiknya yaitu memberikan layanan yang sesuai dengan kebutuhan.

Fokus penelitian mutu pendidikan ini terletak pada proses dan kompetensi Iulusan atau mutu hasil pendidikan karena konsep mutu dalam pendidikan dituangkan dalam bentuk jasa layanan, maka pendidikan yang bermutu adalah pendidikan yang mampu memberikan layanan yang sesuai kebutuhan dan harapan seluruh stakeholders pendidikan. Proses pendidikan di dalamnya terjadi layanan baik dalam bentuk layanan administratif maupun layanan akademik, layanan baik tertuju pada internal pendidikan maupun stakeholders eksternal pendidikan. Mutu hasil pendidikan tertuju pada lulusan peserta didik. Lulusan yang dihasilkan pendidikan dikatakan bermutu apabila dapat memenuhi kebutuhan dan harapan dari seluruh stakeholders pendidikan. Hal ini di dukung dengan teori yang menyatakan bahwa Mutu pendidikan merupakan kesesuaian antara kebutuhan pihak-pihak yang berkepentingan (stakeholder) dengan layanan yang diberikan oleh pengelola pendidikan. Kerangka filosofi pendidikan dalam pengembangan sekolah bermutu 
adalah kesesuaian input, proses dan hasil sekolah dengan kebutuhan para pemangku kepentingan (Sani, dkk., 2015: 6).

Mutu dalam pendidikan mengacu pada proses dan hasil pendidikan. Dalam proses pendidikan terlibat berbagai input, seperti bahan ajar (kognitif, afektif dan psikomotorik) metodologi (bervariasi sesuai kemampuan guru), sarana dan prasarana sekolah, dukungan administrasi, sumber belajar, serta penciptaan suasana yang kondusif. Dukungan kelas yang berfungsi untuk mensinkronkan berbagai input atau mensinergikan seluruh komponen dalam proses belajar mengajar baik antara guru, peserta didik dan sarana pendukung di kelas maupun di luar kelas, baik konteks kurikuler maupun ekstrakurikuler, baik dalam lingkup substansi akademis maupun yang non-akademis dalam suasana yang mendukung proses pembelajaran (Syukur, 2013: 44).

Proses akan dikatakan bermutu apabila pengkoordinasian dan pemaduan input seperti pendidik, peserta didik, kurikulum, sarana dan prasarana, dan biaya dilakukan secara harmonis, sehingga mampu menciptakan situasi pembelajaran yang menyenangkan dan peserta didik mampu mengembangkan dirinya, maka proses pendidikan yang bermutu adalah usaha untuk memfungsikan secara baik dari seluruh komponen pendidikan tersebut. Untuk mencapai pendidikan yang bermutu membutuhkan keterlibatan semua komponen pendidikan. Fokus utamanya adalah sumber daya manusia yang berproses mengusahakan mencapai mutu pendidikan tersebut.

Sumber daya manusia dalam hal ini pendidik dan tenaga kependidikan sebagai salah satu pengarah dalam mencapai mutu pendidikan maka harus melalui proses pendidikan yang efektif dan efisien yaitu melalui perencanaan pendidik dan tenaga kependidikan dengan proses seleksi berdasarkan standar kerja yang dibutuhkan, penempatan pendidik dan tenaga kependidikan sesuai dengan kompetensi yang dimiliki, dilakukan penilaian dan pengembangan untuk meningkatkan produktifitas kerjanya, pemberian kompensasi secara wajar untuk mempertahankan semangat kerjanya dan menjalin hubungan yang harmonis serta adanya pengakuan kreatifitas kerja.

\section{Upaya Peningkatan Mutu Pendidikan Melalui Manajemen Pendidik dan Tenaga Kependidikan di MTs Al-Mansur Biangloe Kabupaten Bantaeng}

Konsep mutu dalam pendidikan dituangkan dalam bentuk jasa layanan, maka pendidikan yang bermutu adalah pendidikan yang mampu memberikan layanan yang sesuai kebutuhan dan harapan seluruh stakeholders pendidikan. Oleh sebab itu fokus mutu pendidikan terletak pada proses dan hasil pendidikan. Proses pendidikan terjadi dengan layanan baik dalam bentuk layanan administratif maupun layanan akademik, layanan baik tertuju pada internal pendidikan maupun stakeholders eksternal pendidikan. Mutu hasil pendidikan tertuju pada lulusan peserta didik. Lulusan yang dihasilkan pendidikan dikatakan bermutu apabila dapat memenuhi kebutuhan dan harapan dari seluruh stakeholders pendidikan. 
Di MTs Al-Mansur Biangloe Kabupaten Bantaeng dalam hal peningkatan mutu pendidikan melalui manajemen pendidik dan tenaga kependidikan, ditemukan berbagai upaya yang dilakukan seperti perencanaan pengadaan pendidik dan tenaga kependidikan melalui proses rekrutmen dan seleksi berdasarkan standar kebutuhan madrasah, pengangkatan dan penempatan pendidik dan tenaga kependidikan pada bidang yang sesuai yaitu kepala madrasah dalam proses penempatan selalu berupaya menyesuaikan antara kebutuhan pekerjaan dengan potensi yang dimiliki, pemberian kompensasi bagi pendidik dan tenaga kependidikan honorer ditentukan oleh madrasah dengan sistem pemberian kompensasi secara adil yang disesuaikan dengan jumlah jam mengajar bagi pendidik dan bagi tenaga pegawai negeri sipil (PNS) ditentukan oleh Undang-Undang no 43 Tahun 1999 tentang penyesuaian gaji pokok PNS, PP no 3 Tahun 2006 tentang Tunjangan Jabatan Struktural, PP no 12 Tahun 2006 tentang Tunjangan Umum bagi pegawai negeri sipil (PNS). Selanjutnya, pengembangan pendidik dan tenaga kependidikan, kepala madrasah sebagai tenaga kependidikan memiliki tanggung jawab dan tugas untuk mengelola pendidikan, termasuk mengelola guru dan stafnya untuk terus mengembangkan kinerjanya. Adapun pengembangan kinerja pendidik dan tenaga kependidikan dilakukan dengan berbagai cara, sebagaimana hasil penelitian di MTs Al-Mansur Biangloe Kabupaten Bantaeng untuk mengembangkan kinerja pendidik dan tenaga kependidikan yaitu mengikuti kegiatan musyawarah guru mata pelajaran (MGMP), mengikuti pelatihan, workshop, seminar, memberikan kesempatan melanjutkan pendidikan dan sertifikasi.

Mutu pendidikan nasional dapat diukur lewat ketercapaian segenap Standar Pendidikan Nasional, meliputi standar isi, proses, kompetensi lulusan, pendidik dan tenaga kependidikan, sarana dan prasarana, pengelolaan, pembiayaan, dan penilaian pendidikan. Perhatian yang serius terhadap upaya pemenuhan segenap standar tersebut akan menentukan mutu pendidikan (Siregar, dkk., 2017: 1).

\section{PENUTUP/SIMPULAN}

Berdasarkan hasil penelitian dan pembahasan yang telah diuraikan pada bagian sebelumnya, maka dapat disimpulkan bahwa pelaksanaan manajemen pendidik dan tenaga kependidikan di MTs Al-Mansur Biangloe Kabupaten Bantaeng ialah aktivitas yang dilakukan mulai dari tenaga kependidikan masuk ke dalam organisasi pendidikan sampai akhirnya berhenti, prosesnya dimulai dengan perencanaan pengadaan pendidik dan tenaga kependidikan melalui rekruitmen dan seleksi, pengangkatan dan penempatan, induksi, pemberian kompensasi, pengawasan dan penilaian, sampai pada pemberhentian pendidik dan tenaga kependidikan sudah berjalan dengan baik, namun masih terdapat proses yang belum maksimal seperti 
proses pengangkatan dan penempatan serta pengkompensasian yang belum mensejahterahkan pendidik dan tenaga kependidikan.

Upaya peningkatan mutu pendidikan melalui pelaksanaan manajemen pendidik dan tenaga kependidikan di MTs Al-Mansur Biangloe Kabupaten Bantaeng adalah melakukan perencanaan dan pengadaan pendidik dan tenaga kependidikan melalui proses rekruitmen dan seleksi, penempatan pendidik dan tenaga kependidikan sesuai kebutuhan madrasah, pengembangan melalui pelatihan, pendidikan dan sertifikasi, pengawasan dan penilaian kinerja, pemberian kompensasi untuk mempertahankan pendidik dan tenaga kependidikan, sekalipun demikian upaya peningkatan mutu MTs Al-Mansur Biangloe Kabupaten Bantaeng belum maksimal, dilihat dari standar pendidik dan tenaga kependidikan yang masih tengah diusahakan untuk memenuhi Standar Nasional Pendidikan.

Sejalan dengan rumusan kesimpulan yang telah dikemukakan maka sebagai saran dari penelitian ini adalah pentingnya kepala madrasah sebagai pemimpin dalam melaksanakan manajemen pendidik dan tenaga kependidikan untuk dilaksanakan secara maksimal dalam upaya meningkatkan mutu pendidikan. Untuk kepentingan tersebut, maka kepala madrasah harus mampu memobilisasi pendidik dan tenaga kependidikan dalam kaitannya dengan perencanaan pengadaan pendidik dan tenaga kependidikan, penempatan yang sesuai kebutuhan, pengembangan, pengawasan dan penilaian kinerja yang dibutuhkan, dan pemberian kompensasi sesuai kinerja dalam hal ini membutuhkan kerjasama serta komitmen yang tinggi dari seluruh penyelenggara pendidikan.

\section{DAFTAR PUSTAKA}

Abdullah Sani, Ridwan, dkk. (2015). Penjaminan Mutu Sekolah. Jakarta: Bumi Aksara.

E. Mulyasa. (2009). Manajemen Berbasis Sekolah. Bandung: Remaja Rosdakarya.

Idris, Ridwan. (2014). Manajemen Pendidikan dalam Aplikasinya di Sekolah. Makassar: Alauddin University Pres.

Karnati, Neti. (2016). Implementasi Manajemen Pendidik dan Tenaga Kependidikan Berbasis Sekolah dalam Peningkatan Mutu Sekolah Dasar di Kota Bekasi. Universitas Negeri Jakarta: Jurnal Parameter, 29(2).

Kasmawati. (2012). Pengembanngan Kinerja Tenaga Kependidikan. Makassar: Alauddin University Press.

Mohamad, Mustari. (2015). Manajemen Pendidikan. Jakarta: Rajawali Pers.

Mudassir. (2016). Pengembangan Sumber Daya Pendidikan di Madrasah Aliyah Negeri (MAN) Kabupaten Bireun. Bireun: Jurnal IImiah Didaktika. 16(2), 255272.

Mukhlisoh. (2018). Manajemen Pendidik dan Tenaga Kependidikan di Madrasah Tsanawiyah Sunan Kalijaga Siwuluh. Kementrian Agama Kabupaten Brebes: Jurnal Kependidikan, 6(2), 233-248 
Siregar, Astri Novia. dkk. (2017). Manajemen Pendidik dan Tenaga Kependidikan dalam Meningkatkan Mutu Pendidikan. Jurnal: Educandum, 10, (1), 1-12.

Tim Dosen Administrasi Pendidikan Universitas Pendidikan Indonesia. (2011). Manajemen Pendidikan. Bandung: Alfabeta.

Sutrisno, Edy. (2014). Manajemen Sumber Daya Manusia. Jakarta: Kencana.

Syukur, Fattah. (2015). Manajemen Sumber Daya Manusia Pendidikan. Semarang: Program Pascasarjana IAIN Walisongo.

Syukur, Fatah. (2013). Manajemen Pendidikan. Semarang: Pustaka Rizki Putra. Wibowo. (2017). Manajemen Kinerja. Depok: Rajawali Pers. 